\title{
Preface to the 1995 Edition
}

Images of Nelson Mandela had graced the world's magazine covers for years. In 1994, when he finally became South Africa's first democratically chosen president, Mandela covers were all but ubiquitous. Still, I was not prepared for the April, 1994, issue of Tribute, a glossy South African monthly, when I saw it on an airport newsstand in Johannesburg. There was Mandela, seated in a black leather chair, dressed in a dark business suit, caught by the camera in the middle of a sentence, with his hands spread to emphasize a point, and beside him, in red letters an inch high, it said simply, "EK IS DIE BAAS." It was an outrageous cover, composed of too many layers of irony to count. The English translation, "I am the boss," conveys none of the menacing resonance of the Afrikaans original: the powerful whiff of the farm foreman, the mine supervisor, the Afrikaner baas barking at his black workers. It was impossible to imagine the courtly liberator Mandela expressing himself so crudely, of course, and the historic election that would make him the country's first black leader was in fact still several weeks away, which only gave the Tribute cover an added jolt of nerviness.

But the idea that Mandela might soon resemble the Afrikaner Nationalists who invented apartheid-the same men who had jailed him for twenty-seven years and banned his movement for thirty, violently oppressing the country's black majority with no more justification, ultimately, than "Ek is die baas"; the same men whom Mandela and his comrades were now furiously campaigning to replace-this idea, when posed by Tribute, was not, I knew, a cry of white alarm or political opposition. For Tribute is a 
black-edited magazine, directed at urban black readers, most of whom were certain to support Mandela's African National Congress in the elections. The cover expressed, rather, a wry, contrarian spirit-a spirit that I thought I recognized, if only because Jon Qwelane, who happens to be the main character of the book you are holding, had become, since my previous visit to South Africa, Tribute's editor. The cover was ostensibly illustrating a story written by Qwelane, in fact, about a day he had recently spent with Mandela. I was shocked by the cover's brilliant cheek, I realized, mostly because I had been away from South Africa for nearly eight years, and had become accustomed to getting my South African news from international sources. I had forgotten how cryptic and multifaceted the South African press can be, how dense with subtext and, for a foreigner, strange enlightenment.

This book was written on the hunch that a close look at a country's newspapers might reveal something otherwise inaccessible about that country's inner life. Its focus is narrow, concentrating on the lives of a small group of black reporters at a large Johannesburg daily, the Star. During the great anti-apartheid uprising of the mid-1980s, their situation seemed to catch an unusual amount of the historical moment's ambient light. That moment passed, and most of the reporters I write about here have, like Qwelane, left the Star; some have left journalism altogether. The country itself is already vastly different from the embattled, repressive place described in these pages.

And yet the South African revolution of 1994 was only a partial affair. Remarkable as it was, it had none of the root-and-branch, Year Zero quality of other world-historical revolutions: 1789 in France, 1917 in Russia, 1949 in China. Most of the chief South African institutions, including the military, the civil service, the stock exchange, and the press, have remained in essentially the same hands. No significant transfer of economic power seems imminent. Of course, this high degree of continuity owes much to the fact that democracy's triumph was, in the end, negotiated rather than won on the battlefield. (The acclaimed peacefulness of the South African transition was only relative, however: more 
than twenty thousand lives were lost to political violence in the last decade of white rule.)

The struggle for social justice will undoubtedly go on-peacefully, with any luck. My own parochial hope is that the censorship, the news blackouts, the official harassment of journalists described in these pages will seem, in a few years, like a dark chapter from a distant South African past. Certainly, a democratically elected government can be held accountable for its actions in ways that the apartheid state never could. At the same time, precious assets, such as press freedom, are always up for grabs. And this, it seems safe to say, was also part of the message in Qwelane's deadpan "EK IS DIE BAAS" cover: a signal to the incoming government that the sweetness of liberation would not be allowed to dilute the acid of his editorial independence.

The deep divisions within the South African press were on vigorous display during the election season. The black press was, on the whole, unabashedly ecstatic about the election. "OH, HAPPY HAPPY DAY!" was the headline over the page-one endorsement of the ANC in Johannesburg's City Press. "We thank God Almighty," that editorial concluded. "Let us go to the polls on Wednesday and vote for a party we can trust with our lives." Sunday Nation began its page-one endorsement of the ANC, "We have come to the eve of our liberation and stand ready to reclaim a right we have been denied for centuries - the right to vote and take charge of our destiny." Meanwhile, the Afrikaans-language press, a bulwark of white-minority rule under the National Party since 1948, inveighed almost as sonorously against the ANC: Rapport, the largest-circulation Afrikaans paper, opined that Mandela's party, if elected, might reveal "the face of a Lenin or a Stalin." And the white-edited English-language papers, such as the Star, virtually all supported the Democratic Party, the long-shot liberal alternative to the ANC and the National Party.

Within these predictable alignments, however, there were a thousand shadings, nuances, exceptions. The Sowetan, the country's largest black daily, split its endorsement berween the ANC and its longtime rival, the Pan Africanist Congress. The Nation- 
alist papers, following the National Party itself, conspicuously abandoned their traditional devotion to "group identity" as they sought to reach black voters with a new, post-apartheid message. State-controlled television and radio, also in the midst of major self-reinvention efforts, endeavored to deliver fair and impartial election coverage - after decades of service as government mouthpieces. The South African press was as multifaceted as ever-it was still a rich trove of social and political information-but the facets themselves were visibly shifting.

Being back in the country for the election, I found myself a member of an invasion force of thousands of foreign journalists. It was a force that tended to mass instantly wherever Mandela or his chief opponent, the incumbent F. W. de Klerk, appeared, or wherever a bomb exploded, and to mill restlessly betweentimes, hungry for fresh angles but often uncertain where to find them. Many local journalists went to work for the visitors, who were paying extremely well. And the technical sophistication of some of the foreign news crews seemed to overawe some of their South African counterparts. At the same time, many local reporters were nonplussed by the tenacious, even exclusive, interest in political violence and famous faces among much of the international press. While the world spotlight worked, inevitably, to flatten the South African election story, oversimplifying or sensationalizing events for distant audiences, it also served as a sort of object lesson in journalistic self-absorption for local hacks. Having a foot, in effect, in both worlds, I found myself obliged to explain to incredulous local reporters how it was that Dan Rather might indeed have a dimple on his chin redrawn by a makeup artist before each broadcast.

The split in my own journalistic vision was, in fact, pervasive. After a televised debate between Mandela and de Klerk that had been broadcast worldwide, for instance, I called an editor in New York who reported that he and other Americans had been "incredibly moved" by a handshake, initiated by Mandela, between the two men near the end of the debate. I was speechless, mainly because the group with whom I had watched the debate, a group made up of local journalists and ANC supporters, had hooted and 
booed the handshake as hackneyed, unnecessary, and obviously scripted. What was more, I had shared their cynical view. This was a group of South Africans whose collective joy over the approaching election was deep and abiding. The televised handshake had simply not meant the same things to them-or to me, as it happened-that it evidently did overseas. I mumbled something to the editor about trying to work the handshake into a column I was writing. (I didn't succeed.) My split vision, contracted in part while researching this book, could be inconvenient; still, I was not unhappy to note that after only a few weeks back in South Africa I was already immersed in local ambiguities that could not be neatly summarized.

In an epilogue to this edition I try to summarize, neatly where possible, recent events in the lives of the main characters of Dateline Soweto, as well as developments in some of the communities and institutions that figure in the book. I am delighted to admit, incidentally, that one prediction of mine, about the likely future course of events in South Africa as a whole, looks to have been far off the mark. At the end of Chapter 9, while dismissing a business executive's rosy, neo-colonial fantasy of what the country might look like in the year 2000 , I wrote that the blasted, war-torn land of J. M. Coetzee's Life and Times of Michael $K$ provided a more plausible forecast. It did not. (Nor, as a work of the imagination, was it meant as a simple forecast.) I will leave this blaring misjudgment, along with its less obvious cousins, in place on the theory that the main body of Dateline Soweto should be read as a product of its time, as testimony from an apocalyptic period, with all the distortions that implies. What has actually happened in South Africa since then-the swift, unstoppable transition to true parliamentary democracy - has been more stunning, more dreamlike, than anything anyone could imagine even a few years ago. 
